\title{
PENERAPAN PEMBELAJARAN PROBLEM POSING UNTUK MENINGKATKAN HASIL BELAJAR SISWA KELAS X MIA 6 SMAN 1 KOTA BIMA
}

\author{
Abdul Muis* \\ SMA Negeri 1 Kota Bima, Jl. Soekarno-Hatta Raba-Bima NTB \\ "Email korespondensi: muismbojo68@gmail.com
}

\begin{abstract}
ABSTRAK
Penelitian ini bertujuan untuk mendeskripsikan pembelajaran dengan problem posing yang dapat meningkatkan hasil belajar siswa kelas X MIA.6 SMAN 1 Kota Bima tahun pelajaran 2016/2017 pada pokok bahasan trigonometri. Langkah-langkah dalam pembelajaran problem posing yaitu: (1) Guru menjelaskan materi pelajaran kepada siswa, (2) Guru memberikan latihan soal secukupnya, (3) Siswa diminta mengajukan 1 atau 2 soal yang menantang, tetapi siswa yang bersangkutan harus mampu menyelesaikannya, dan (4) Pada pertemuan berikutnya secara acak guru menyuruh siswa untuk menyajikan soal dan menyelesaikannya di depan kelas. Penelitian ini dilaksanakan dalam dua siklus. Pada setiap siklus dilaksanakan empat kali pertemuan. Data yang dikumpulkan adalah data kuantitatif yang diperoleh melalui penilaian tes akhir siklus I dan tes akhir siklus II. Hasil penelitian menunjukkan bahwa pada siklus I dengan materi ajar "Identitas dan Pembuktian", terdapat 27 siswa $(79,41 \%)$ telah mencapai KKM, sedangkan 7 siswa $(20,59 \%)$ belum mencapai KKM. Hasil yang dicapai tersebut belum mencapai target keberhasilan minimal sebesar 85\%. Penerapan pembelajaran dengan problem posing pada siklus II dengan materi ajar "Grafik Fungsi Trigonometri", terdapat 31 siswa $(91,18 \%)$ telah mencapai KKM, sedangkan 3 siswa $(8,82 \%)$ belum mencapai KKM. Kondisi ini menunjukkan bahwa pada siklus II terdapat peningkatan hasil belajar yang sangat signifikan dicapai siswa, yaitu telah melampau target keberhasilan minimal sebesar $85 \%$, sehingga dapat disimpulkan bahwa penerapan model problem posing telah meningkatkan hasil belajar siswa kelas X MIA 6 SMAN 1 Kota Bima tahun pelajaran 2016/2017, khusunya pada pokok bahasan Trigonometri.
\end{abstract}

Kata Kunci: Hasil belajar, Trigonometri, Problem Posing.

\begin{abstract}
This study aims to describe learning with problem posing that can improve learning outcomes of students of class X MIA. 6 SMAN 1 Kota Bima in the academic year 2016/2017 on trigonometry. The steps in problem posing learning are: (1) The teacher explains the subject matter to students, (2) The teacher provides enough practice questions, (3) Students are asked to submit 1 or 2 challenging questions, but the student must be able to solve them, and (4) At the next meeting randomly the teacher tells students to present the problem and finish it in front of the class. This research was conducted in two cycles. In each cycle four meetings were held. The data collected is quantitative data obtained through the assessment of the final test of the first cycle and the final test of the second cycle. The results showed that in the first cycle with "Identity and Proof" teaching material, there were 27 students $(79.41 \%)$ who had achieved the Minimum Completion Criteria, while 7 students (20.59\%) had not reached the Minimum Completion Criteria. The results achieved have not yet reached the minimum success target of $85 \%$. The application of learning with problem posing in cycle II with teaching material "Graph of Trigonometric Functions", there were 31 students (91.18\%) who had reached the Minimum Completion Criteria, while 3 students (8.82\%) had not reached the Minimum Completion Criteria. This condition shows that in the second cycle there was a very significant increase in learning outcomes achieved by students, which has exceeded the minimum target of success of $85 \%$, so it can be concluded that the application of the
\end{abstract}


problem posing model has improved the learning outcomes of students of class X MIA 6 in Bima 2016/2017, especially on the subject of Trigonometry.

Keywords: Learning outcomes, Trigonometry, Problem Posing.

\section{PENDAHULUAN}

Pembelajaran konvensional yang diterapkan pada kelas X MIA 6 reguler SMA Negeri 1 Kota Bima tahun pelajaran 2016/2017 kurang mampu mendorong siswa berpikir kritis dan mengkonstruksi sendiri pengetahuannya dalam menyelesaikan persoalan matematika. Akibatnya siswa tidak berperan aktif secara mental dalam proses pembelajaran, enggan mengajukan pertanyaan ataupun mengemukakan pendapat. Ketika proses belajar mengajar sedang berlangsung, terdapat siswa yang menggarok kepala, melamun, sering memandang kearah luar kelas, meminta izin keluar kelas untuk beli buku dan bolpint, tidak mengerjakan tugas yang diberikan guru, tidak mampu menerapkan konsep matematika yang telah diajarkan.

Pada pembelajaran materi trigonometri, guru masih kental dengan pembelajaran konvensional yang sifatnya cenderung berpusat pada guru yang hanya berfokus pada latihan soal yang bersifat prosedural dan mekanistik dari pada mendorong siswa untuk berpikir kreatif dan kritis. Kebanyakan siswa kelas X MIA 6 cenderung menghafal rumus dan langkahlangkah penyelesaian soal yang dicontohkan oleh guru tanpa memahami cara penerapan konsep yang telah dipelajarinya. Pada sisi lain, untuk menerapkan model-model pembelajaran yang menganut paham konstruktivisme seperti pembelajaran kooperatif, pembelajaran kontekstual, maupun pembelajaran berbasis pemecahan masalah (soal) belum dipahami oleh kebanyakan guru.

National Council of Teachers of Mathematics (NCTM) tentang standar proses pembelajaran matematika (dalam Subanji, 2013:88) menyatakan, bahwa dalam mengkondisikan siswa untuk berinteraksi, guru matematika harus melibatkan siswa untuk: (a) mendengarkan dan merespon pertanyaan dari gurunya, (b) berdiskusi untuk memecahkan masalah dan berkomunikasi matematika, (c) mengajukan masalah dan pertanyaan, (d) membuat dugaan dan solusinya, (e) menelusuri atau mengeksplorasi contoh dan penyanggah untuk menyelidiki suatu dugaan, (f) mencoba untuk meyakinkan dirinya sendiri dan orang lain terhadap representasi dari solusi, dugaan dan jawaban, dan (g) menggunakan bukti dan argumen secara matematika untuk menentukan validitas atau kebenaran. 
Partisipasi aktif siswa dalam pembelajaran perlu diperhatikan oleh guru agar siswa mampu mengkonstruksi sendiri pengetahuan baru berdasarkan pengalaman dan pengetahuan yang diperoleh sebelumnya untuk menyelesaikan tugas-tugas matematika. Oleh karena itu, guru perlu mendorong dan memotivasi siswa untuk berperan aktif dalam menyelesaikan masalah (soal) yang diajukan guru dan yang diajukan oleh siswa dari kelompok lain dalam kelasnya. Menurut Ruseffendi (1980: 216), suatu persoalan itu merupakan masalah bagi siswa, pertama: bila persoalan itu tidak dikenalnya, yakni siswa belum memiliki prosedur atau algoritma tertentu untuk menyelesaikannya, kedua: siswa harus mampu menyelesaikannya, baik kesiapan mentalnya maupun pengetahuan siapnya, terlepas daripada apakah akhirnya ia sampai atau tidak kepada jawabannya, dan ketiga: sesuatu itu merupakan pemecahan masalah baginya, bila ia ada niat menyelesaikannya.

Menurut Subanji (2013:84), pembelajaran yang berorientasi pada pemberdayaan berpikir siswa, nampaknya merupakan keharusan yang tidak dapat ditunda lagi, karena hakekat pembelajaran adalah mengembangkan berpikir siswa, sehingga mampu memecahkan masalah-masalah dalam kehidupan yang cukup dinamis. Siswa yang terlibat secara aktif dalam pembelajaran dengan pemecahan masalah memiliki perilaku dan pemikiran kreatif dalam mencari solusi dari masalah yang dihadapinya, karena dalam pemecahan masalah membutuhkan kedua unsur tersebut. Untuk mengembangkan kreatif dan kritis siswa dalam menyelesaikan atau memecahkan masalah matematika, guru dapat menggunakan model pembelajaran kooperatif, seperti: problem posing. Bentuk problem posing yang digunakan dalam penelitian ini adalah post solution posing, yaitu pembelajaran diawali dengan pengajuan soal oleh guru kepada masing-masing kelompok belajar, setelah guru melakukan tanya-jawab untuk menggali pengetahuan prasyarat siswa, menyampaikan tujuan pembelajaran, dan menguraikan materi ajar secara garis besar. Selanjutnya siswa dituntut untuk membuat soal baru yang berkaitan dengan materi yang dipelajari dan menyelesaikannya sendiri secara berkelompok, kemudian mengajukan kepada salah satu kelompok lain, Masing-masing kelompok menyelesaikan soal yang diajukan oleh kelompok lain dan mempresentasikan cara penyelesainnya di depan kelas Proses selanjutnya dilakukan dengan cara yang sama hingga batas waktu yang ditentukan dalam rencana pelaksanaan pembelajaran (RPP).

Darbas dan Cancoy menemukan bahwa pembelajaran dengan problem solving berbasis problem posing dapat meningkatkan pemahaman matematika peserta didik. Guversin, Kaya, 
dan Kesan menemukan bahwa problem posing berpengaruh pada peningkatan kemampuan matematika peserta didik dan meningkatkan interaksi peserta didik dalam belajar matematika. Bakar dan Norman menjelaskan bahwa peserta didik mampu mengubah data yang diketahui dalam mengajukan masalah dan perilaku problem posing peserta didik terus mengalami perkembangan dalam proses pembelajaran (dalam Subanji, 2013:136). Hasil penelitian Hidayah yang dimuat dalam majalah "Ilmiah Faktor" vol. 1 No. 1 Januari 2013, menyatakan bahwa penerapan metode problem posing dapat meningkatkan aktivitas siswa SMPN 209 Jakarta tahun akdemik 2012/2013 dalam proses belajar mengajar, terutama berinteraksi dan berbagi ide pada siswa satu sama lain dan guru sehingga kegiatan belajar mengajar bermakna. Hasil penelitian Jabar yang dipublikasiakan dalam jurnal pendidikan matematika " Math Didactic" vol. 1 No. 2 Mei-Agustus 2015, menyatakan bahwa penerapan pendekatan problem posing dapat meningkatkan kemampuan pemecahan masalah matematika siswa kelas X A program studi multimedia SMK Negeri 3 Banjarmasin pada materi sistem persamaan linear.

Bertitik tolak dari latar belakang masalah di atas dan juga mengingat bahwa di SMA Negeri 1 Kota Bima selama ini belum pernah dilakukan penelitian pembelajaran melalui problem posting dalam pembelajaran matematika, maka peneliti memandang perlu untuk melakukan penelitian dengan judul: "Penerapan Pembelajaran Problem Posing Untuk Meningkatkan Hasil Belajar Siswa Kelas X MIA.6 SMAN 1 Kota Bima”. Penelitian ini bertujuan untuk mendeskripsikan pembelajaran dengan problem posing yang dapat meningkatkan hasil belajar siswa kelas X MIA.6 SMAN 1 Kota Bima tahun pelajaran 2016/2017.

Pemilihan problem posing sebagai model pembelajaran untuk digunakan dalam penelitian ini didasarkan pada pertimbangan peneliti dengan melihat beberapa keunggulannya, yaitu sebagai berikut: (1) pembelajaran berpusat pada siswa, (2) orientasi pembelajaran adalah pemecahan masalah (soal), (3) dapat meningkatkan kemampuan siswa berpikir kritis, dan (4) dapat mengaktifkan siswa dalam proses pembelajaran. Adapun tipe model pembelajaran problem posing yang digunakan penulis dalam penelitian tindakan kelas ini, yakni problem posing tipe post solution posing.

\section{METODE PENELITIAN}


Penelitian ini dilaksanakan di kelas X MIA.6 SMAN 1 Kota Bima tahun ajaran 2016/2017. Subjek penelitian adalah siswa-siswa kelas X MIA 6 sebanyak 34 orang, yang terdiri dari 13 siswa laki-laki dan 21 siswa perempuan. Subjek penelitian ini sangat heterogen dilihat dari kemampuannya, yakni ada sebagian siswa mempunyai kemampuan tinggi, sedang, rendah, dan sangat rendah. Pelaksanaan penelitian dimulai awal Pebruari 2017 s.d 29 Maret 2017.

Rancangan penelitian yang digunakan dalam penelitian ini adalah rancangan penelitian tindakan kelas (PTK) dan dilakukan sebanyak 2 (dua) siklus pembelajaran. Pada masingmasing siklus dilaksanakan 4 (empat) kali pertemuan. Untuk mendapatkan data hasil belajar siswa kelas X MIA 6 dilakukan melalui proses kegiatan belajar mengajar di kelas secara formal, yaitu berdasarkan jadwal mengajar yang ditetapkan sekolah. Tes dilaksanakan pada pertemuan ke-4 untuk masing-masing siklus. Penilaian hasil belajar siswa menggunakan pedoman penilaian analitik. Data aktivitas guru dan aktivitas siswa diperoleh melalui hasil pengamatan pengamat menggunakan lembar pengamatan. Sumber datanya yaitu: siswa, peneliti, dan pengamat. Data tentang hasil belajar siswa pada masing-masing siklus dianalisis menggunakan statistik deskriptif, yaitu berupa persentase.

Adapun indikator kerja atau indikator keberhasilan dalam penelitian ini, yaitu: hasil belajar siswa dianggap berhasil meningkat secara klasikal, apabila hasil tes yang dicapai siswa dalam suatu siklus dibandingkan dengan hasil belajar sebelum menerapkan pembelajaran dengan problem posing mengalami peningkatan minimal $85 \%$ siswa yang sudah mencapai KKM = 75. Ketercapaian tersebut juga didukung hasil penilain terhadap observasi keterlaksanaan pembelajaran probelm posing oleh pengamat yang berupa penilaian terhadap aktivitas guru dan aktivitas siswa berada pada kriteria baik.

Kehadiran dan keterlibatan peneliti secara langsung di dalam kancah penelitian sangat penting, karena: (1) akan menambah keakraban antara peneliti dan subjek penelitian, (2) peneliti menyusun rancangan penelitian dan lebih memahami bagaimana pelaksanaannya, (3) peneliti menyusun perangkat pembelajaran, sehingga lebih memahami langkah-langkah penerapannya, dan (3) peneliti perlu menghayati apa yang sebenanya terjadi dalam proses pembelajaran.

Untuk mengecek keabsahan data digunakan triangulasi, ketekunan pengamatan, dan pengecekan teman sejawat. Triangulasi dilakukan dengan membandingkan data hasil 
observasi teman sejawat dengan data hasil observasi peneliti. Ketekunan pengamatan, yaitu melakukan pengamatan secara kontinu dengan teliti selama kegiatan penelitian. Pengecekan sejawat, yaitu mendiskusikan proses dan hasil penelitian dengan teman sejawat untuk mempertahankan sikap keterbukaan dan kejujuran.

\section{HASIL DAN PEMBAHASAN}

Pembelajaran dengan problem posing dalam siklus I dilaksanakan dalam empat kali pertemuan. Pengamat berpendapat bahwa aktivitas guru dan siswa dalam tindakan I dinilai sangat baik. Pada pertemuan keemapt dilaksanan tes akhir siklus I. Hasil belajar dari 34 siswa yang dicapai sebelum diadakan tindakan---sebelum dilaksanakan penelitian--- dengan materi ajar yaitu "Perbandingan Trigonometri" terdapat 23 siswa (67,6\%) yang telah mencapai KKM dan 11 siswa $(32,4 \%)$ yang belum mencapai KKM. Setelah diadakan tindakan berupa penerapan model problem posing dalam pembelajaran dengan materi ajar" Identitas dan Pembuktian trigonometri", hasil belajar siswa pada tes akhir tindakan I terdapat 27 siswa $(79,41 \%)$ yang telah mencapai KKM dan 7 siswa $(20,59 \%)$ yang belum mencapai KKM. Tampak hasil belajar siswa yang dicapai pada siklus I mengalami peningkatan, namun belum mencapai $85 \%$, sehingga penelitian harus dilanjutkan pada siklus II. Data yang diperoleh dari hasil tes sebelum tindakan pada siklus I merupakan data awal yang dipergunakan sebagai acuan dalam menentukan apakah ada/tidaknya peningkatan hasil belajar siswa yang telah dicapai pada siklus (tindakan) berikutnya.

Selanjutnya, sebelum melaksanakan pembelajaran dengan problem posing pada tindakan II, peneliti dan pengamat melakukan tefleksi terhadap pelaksanan dan hasil yang dicapai pada tindakan I dengan tujuan untuk tindakan perbaikan terhadap kekurangan yang ditemukan dalam tindakan I. Pada tindakan II, pelaksanaan tes dilakukan pada pertemuan keempat. Hasil tes akhir pada siklus II dengan materi ajar "Grafik Fungsi Trigonometri" terdapat 31 siswa $(91,18 \%)$ yang telah mencapai KKM dan 3 siswa $(8,82 \%)$ yang belum mencapai KKM. Peningkatan hasil belajar siswa pada siklus II tersebut telah melampau batas minimalr keberhasilan, yaitu minimal $85 \%$ yang telah mencapai $\mathrm{KKM}=75$.

Berdasarkan hasil belajar siswa yang dicapai pada tindakan II di atas, maka tidak perlu dilakukan tindakan perbaikan ataupun melanjutkan pembelajaran pada tindakan selanjutnya. Selama berlangsungnya proses pembelajaran pada tindakan II, interaksi siswa dengan siswa dalam kelompoknya semakin lancar. Hal ini disebabkan semakin aktifnya 
peranan siswa (tutor sebaya) membimbing anggotanya, juga adanya keberanian siswa berkemampuan rendah dalam berinteraksi dengan sesama anggota dalam kelompoknya.

Berdasarkah hasil analisis data sebelum tindakan, pada tindakan I, dan tindakan II di atas dapat ditentukan besar peningkatan hasil belajar siswa yang telah dicapai seperti yang tampak pada tabel berikut ini.

Tabel 1. Hasil Belajar Siswa Sebelum dan Setelah Menerapkan Pembelajaran dengan Problem Posing.

\begin{tabular}{lcc}
\hline \multicolumn{1}{c}{ Tindakan } & Tuntas & Belum Tuntas \\
\hline Sebelum tindakan & $67,6 \%(23$ siswa $)$ & $32,4 \%(11$ siswa $)$ \\
Siklus I & $79,41 \%(27$ siswa $)$ & $20,59 \%(7$ siswa $)$ \\
Siklus II & $91,18 \%(31$ siswa $)$ & $8,82 \%(3$ siswa $)$ \\
\hline
\end{tabular}

Berdasarkan data pada tabel di atas, tampak bahwa hasil belajar siswa yang dicapai pada tindakan II mengalami peningkatan sebesar 91,18 \% (31 siswa) yang mencapai KKM. Berdasarkan indikator kerja atau indikator keberhasilan dalam penelitian ini, yaitu: hasil belajar siswa dianggap berhasil meningkat secara klasikal, apabila hasil tes yang dicapai siswa dalam suatu siklus dibandingkan dengan hasil belajar sebelum menerapkan pembelajaran dengan problem posing mengalami peningkatan minimal $85 \%$ siswa yang sudah mencapai $\mathrm{KKM}=75$.

Pembelajaran dengan problem posing merupakan salah satu model pembelajaran yang diawali dengan pengajuan soal oleh guru kepada kelompok belajar siswa setelah dilakukan pembahasan materi ajar secara garis besar. Siswa berusaha mengkonstruksi sendiri pengetahuan yang diperoleh pada pengalaman belajar sebelumnya untuk menemukan cara penyelesaian soal yang diajukan. Cara penyelesaian soal yang ditemukan siswa merupakan sesuatu yang baru dan bermakna baginya. Gagne (dalam Wena, 2011:52) berpendapat, sesuatu yang baru dimaksud adalah perangkat prosedur atau strategi yang memungkinkan siswa dapat meningkatkan kemandirian dalam berpikir. Bila terdapat kesalahan jawaban siswa, guru menentukan konteks persoalan, kemudian memberikan soal pancingan sesuai kesalahan jawaban siswa, memberikan bimbingan dengan sederet pertanyaan bersifat lisan ataupun secara tertulis. Hal ini dimaksudkan agar kesulitan yang dialami siswa dalam menyelesaikan soal baik yang diajukan guru maupun yang diajukan siswa yang bukan pada kelompoknya dapat diatasi lebih awal. Menurut Hudojo (2005:75), tidak dapat diharapkan bahwa semua siswa akan mampu menemukan hubungan dari prinsip-prinsip yang telah 
dipelajari sebelumnya atas inisiatif siswa sendiri. Kebanyakan siswa memerlukan bimbingan dan petunjuk yang berupa secara lisan ataupun secara tertulis dengan sederet pertanyaan dan penjelasan. Melalui pembelajaran dengan problem posing, siswa dilatih untuk membuat soal yang sama seperti yang diajukan guru dan menemukan sendiri prosedur penyelesaian soal yang diajukan sebelum diajukan kepada kelompok lain, mengalami, dan juga manarik kesimpulan sendiri akan menjadi pengetahuan yang dikonstruksi sendiri melalui pengalaman belajar.

\section{KESIMPULAN}

Data yang terdapat pada tabel bagian hasil dan pembahasan di atas, menggambarkan hasil belajar yang dicapai siswa sebelum tindakan dan sesudah diterapkan pembelajaran dengan model problem posing. Berdasarkan data hasil penelitian tersebut, hasil belajar siswa yang dicapai pada siklus I yang telah mencapai KKM, sebesar 79,41\% (27 siswa) belum memenuhi indikator kerja meskipun mengalami peningkatan, sedangkan hasil belajar siswa pada siklus II yang telah mencapai KKM, sebesar 91,18 \% (31 siswa) telah memenuhi indikator kerja yang digunakan dalam penelitian. Dengan demikian dapat disimpulkan, bahwa penerapan model problem posing telah meningkatkan hasil belajar siswa kelas X MIA 6 SMAN 1 Kota Bima tahun pelajaran 2016/2017, khusunya pada pokok bahasan Trigonometri.

\section{REKOMENDASI}

Selanjutnya, berdasarkan hasil penelitian dengan penerapan model problem posing ini, peneliti merekomendasikan kepada:

1. Guru matematika dan IPA pada umumnya, perlu menerapkan pembelajaran dengan problem posing atau mengembangkan model pembelajaran lain yang sesuai dengan kondisi kelas untuk meningkatkan hasil belajar siswa. Sebelum menerapkan pembelajaran problem posing di kelas, guru perlu memahami langkah-langkah pelaksanaan problem posing dan maksud yang terkandung pada setiap langkah yang ada. Penelitian tindakan kelas hendaknya dapat dilakukan para guru untuk mengembangkan model pembelajaran yang berpusat pada siswa guna meningkatkan profesionalisme guru sebagai bentuk upaya dalam meningkatkan hasil belajar siswa. 
2. Siswa. Berlatihlah untuk membuat soal sendiri seperti yang dicontohkan guru atau yang lebih menantang, dan gunakan pengalaman belajar untuk mengkonstruksi sendiri pengetahuan dalam menyelesaikan soal atau masalah.

3. Peneliti lain, penerapan problem posing untuk meningkatkan hasil belajar siswa dalam penelitian ini masih terbatas, untuk itu perlu adanya penelitian lanjutan dengan masalah yang lain.

\section{UCAPAN TERIMAKASIH}

Puji syukur penulis panjatkan kehadirat Allah SWT yang telah mencurahkan nikmat, diantaranya nikmat sehat dan kesempatan. Berkat nikmat sehat dan kesempatan, penulis mampu berpikir dan berbuat dalam menyelesaikan penelitian hingga pembuatan laporan hasil penelitian dengan judul "Penerapan Pembelajaran Problem Posing untuk Meningkatkan Hasil Belajar Siswa Kelas X MIA.6 SMAN 1 Kota Bima.

Penulis menyadari sepenuhnya bahwa proses penyelesaian penelitian hingga sampai penulisan laporan hasil penelitian ini atas kerjasama dan bantuan dari berbagai pihak. Oleh karena itu, dalam kesempatan ini penulis menyampaikan terima kasih dan penghargaan yang setinggi-tingginya kepada Ibu Endhie Anie Alifia, S.Si, Yudi Ananto, S.Pd selaku pengamat yang banyak memberikan bantuan dalam penelitian, dan juga terima kasih banyak untuk teman-teman guru SMAN I Kota Bima yang telah banyak membantu penyelesaian pelaksanaan penelitian hingga pembuatan laporan hasil penelitian.

\section{REFERENSI}

Direktorat Jenderal Guru dan Tenaga Kependidikan. (2016). Guru Pembelajar Modul Matematika SMA, Kelompok Kompetensi E, Strategi Pembelajaran 2, Pengembangan Indikator dan Materi. Jakarta : Direktorat Jenderal Guru dan Tenaga Kependidikan.

Hidayah, Aeni, dan Aryanti. (2013). Pengaruh Penerapan Metode Problem Posing terhadap Hasil Belajar Matematika Siswa SMPN 209 Jakarta. https://www.researchgate.net. Majalah Ilmiah Faktor, vol. 1 No. 1, Januari 2013, diakses 7 Januari 2017.

Hudojo, H. (2005). Pengembangan Kurikulum dan Pembelajaran Matematika. Malang: Universitas Negeri Malang.

Jabar, A. (2015). Penerapan Pendekatan Problem Posing untuk Meningkatkan Kemampuan Pemecahan Masalah Matematika Siswa SMK Negeri 3 Banjarmasin. 
https://media.neliti.com. Jurnal Math Didactic, vol. 1 No. 1, Mei-Agustus 2015, diakses 7 Januari 2017.

Ruseffendi, E.T. (1980). Pengajaran Matematika Modern Untuk Orang Tua Murid, Guru, dan SPG. Bandung: Tarsito. Seri Kelima.

Subanji. (2013). Pembelajaran Matematika Kreatif dan Inovatif. Malang: Universitas Negeri Malang (UM).

Sutiarso, S. (1999). Pengaruh Pembelajaran dengan Pendekatan Problem Posing terhadap Hasil Belajar Aritmetika Siswa SMPN 18 Malang. Tesis Tidak Diterbitkan. Malang: PPs UM.

Wena, M. (2011). Strategi Pembelajaran Inovatif Kontemporer Suatu Tinjauan Konseptual Operasional. Jakarta Timur: PT Bumi Aksara. Cetakan Keenam. 